\title{
Tuberkulosis tonsil dan nasofaring disertai limfadenopati servikal dan tuberkulosis milier
}

\author{
Rina Hayati, Abdul Rachman Saragih \\ Departemen Ilmu Penyakit Telinga Hidung Tenggorok \\ Fakultas Kedokteran Universitas Sumatera Utara \\ Rumah Sakit Umum Pusat Haji Adam Malik
}

Medan

\begin{abstract}
ABSTRAK
Latar belakang: tuberkulosis pada saluran nafas atas sangat jarang dijumpai dan biasanya disertai dengan penyakit paru primer. Dengan kemajuan pengobatan tuberkulosis saat ini, infeksi mycobacterium pada tonsil dan nasofaring jarang dijumpai. Limfadenopati servikal merupakan simptom yang sering terjadi, dan seharusnya didiagnosis banding dengan suatu massa di kepala dan leher. Tujuan: untuk menambah pengetahuan dalam mendiagnosis dan menangani tuberkulosis tonsil dan nasofaring yang jarang dijumpai. Kasus: Seorang anak laki-laki 14 tahun dikonsulkan dengan masa dileher bilateral disertai disfagia, demam dan malaise selama satu bulan. Penatalaksanaan: Pasien awalnya kami diagnosis banding sebagai suatu massa di kepala leher. Setelah ditegakkan diagnosis sebagai tuberkulosis tonsil dan nasofaring disertai limfadenopati servikal dan tuberkulosis milier, diberikan terapi dengan anti tuberkulosis dan diperoleh hasil yang baik. Kesimpulan: Tuberkulosis sebaiknya dimasukkan sebagai diagnosis banding suatu massa di kepala dan leher terutama jika gambaran klinis dan pencitraan yang dijumpai tidak khas, sementara itu biopsi dan gambaran mikrobiologi selalu harus dipertimbangkan.
\end{abstract}

Kata kunci: tuberkulosis nasofaring, tonsil, millier, limfadenopati.

\begin{abstract}
Background: Tuberculosis (TB) of the upper aerodigestive tract is rare and is usually associated with primary pulmonary disease. With recent advances in medical treatment of tuberculosis, mycobacterial infection of the nasopharynx and tonsil becomes very rare. The most common presenting symptom is cervical lymphadenopathy, so TB should be considered in the differential diagnosis of soft tissue masses of the head and neck. Purpose: To remind Otolaryngologists about the diagnosis and management of nasopharyngeal and tonsillar tuberculosis, which become rare case nowadays. Case: A 14-year-old boy was consulted with bilateral neck masses, disphagia, fever and malaise for one month. Case Management: At first we made a differential diagnosis of soft tissue masses of the head and neck. After he was diagnosed as nasopharyngeal and tonsilar tuberculosis with cervical lymphadenopathy and millier tuberculosis, the patient was treated with anti tuberculosis medication and the result was good. Conclusion: TB should be considered in the differential diagnosis of soft tissue masses of the head and neck, particularly when the imaging findings and clinical presentation are atypical, at which point appropriate biopsies and microbiologic studies should be conducted.
\end{abstract}

Keyword: Nasopharyngeal tuberculosis, tonsilar tuberculosis, cervical lymphadenopathy, millier tuberculosis

Alamat Korespondensi: Rina Hayati. Department of Otorhinolaryngology Head and Neck Surgery FK USU-RSAM. Jl. Bunga Lau no: 17, Medan. Email: rinaalfa10@gmail.com. 


\section{PENDAHULUAN}

Tuberkulosis (TB) merupakan salah satu penyakit tertua pada manusia, bahkan sampai saat ini masih merupakan penyakit dengan insidens tertinggi dan menjadi penyebab utama kematian manusia. Sekitar 9 juta orang di seluruh dunia pada tahun 2002 menderita TB, dan 2 juta di antaranya meninggal karena penyakit tersebut. TB diketahui dapat mengenai hampir setiap organ dalam tubuh, dan itu harus menjadi perhatian dari setiap praktisi medis. ${ }^{1}$

Tuberkulosis (TB) adalah penyakit yang dominan terdapat di paru, meskipun hampir semua organ dan sistem dapat diserang oleh basil tuberkulosis melalui penyebaran secara hematogen. TB yang terisolasi pada saluran aerodigestif atas jarang dijumpai dan biasanya dikaitkan dengan penyakit paru primer. $^{2}$

Dengan kemajuan pengobatan tuberkulosis, infeksi mikobakteri pada nasofaring dan tonsil sudah jarang dijumpai. Gejala yang paling umum dijumpai adalah limfadenopati servikal sehingga seringkali didiagnosis banding dengan keganasan kepala dan leher.

Diagnosis dapat ditegakkan melalui pemeriksaan histopatologi jaringan. ${ }^{3}$
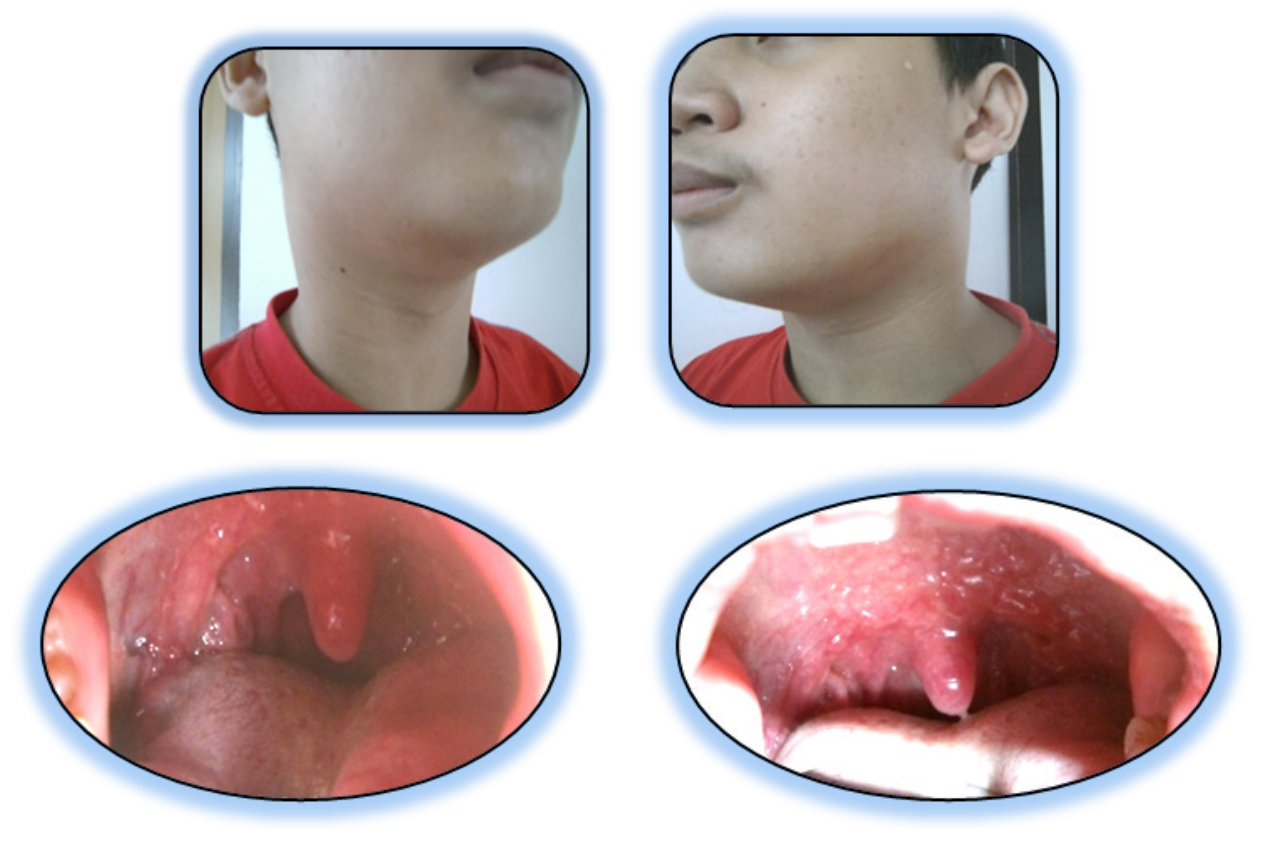

Gambar 1. Limfadenopati servikal disertai pembesaran tonsil
Dilaporkan suatu kasus jarang yaitu TB nasofaring dan tonsil disertai limfadenopati servikal dan TB milier secara bersamaan, yang awalnya didiagnosis banding sebagai suatu keganasan kepala-leher. Kasus ini diterapi dengan obat anti tuberkulosis dengan hasil yang baik.

\section{LAPORAN KASUS}

Seorang laki-laki usia 14 tahun dikonsulkan dari dokter spesialis anak di RS Permata Bunda tanggal 29 januari 2013, dengan benjolan di leher bilateral sejak satu bulan sebelumnya. Keluhan lain berupa disfagia, odinofagia, demam dan malaise. Tidak ada riwayat tinitus, epistaksis dan sumbatan pada hidung. Riwayat kebiasaan yang menjadi faktor risiko HIV seperti penggunaan narkoba suntikan, aktivitas homoseksual dan penyakit menular seksual disangkal. Riwayat tuberkulosis paru dan riwayat terpapar dengan penderita tuberkulosis paru disangkal. Riwayat keluarga dengan tuberkulosis paru maupun keganasan juga disangkal. 
Pemeriksaan fisik didapati pembengkakan kelenjar getah bening di leher, bilateral. Benjolan berbatas tegas, permukaan pucat, mobile dengan ukuran 9x7x3 cm pada leher kanan dan $7 \times 5 \times 4 \mathrm{~cm}$ pada leher kiri (gambar 1). Pada pemeriksaan rinoskopi anterior tidak dijumpai kelainan. Pemeriksaan orofaring dan rinoskopi posterior dijumpai massa pada tonsil dan dinding nasofaring kanan dengan permukaan tidak rata nampak seperti gigitan tikus (mouse bites) disertai dengan sedikit ulserasi.
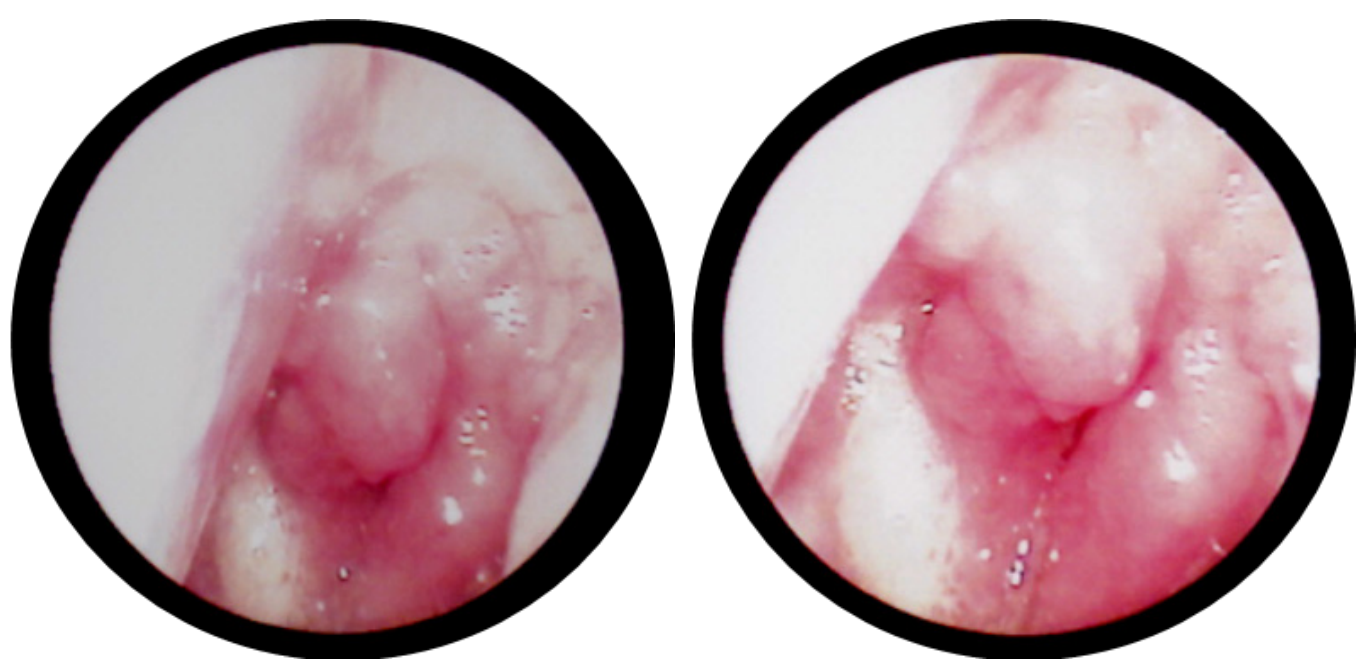

Gambar 2. Endoskopi nasofaring
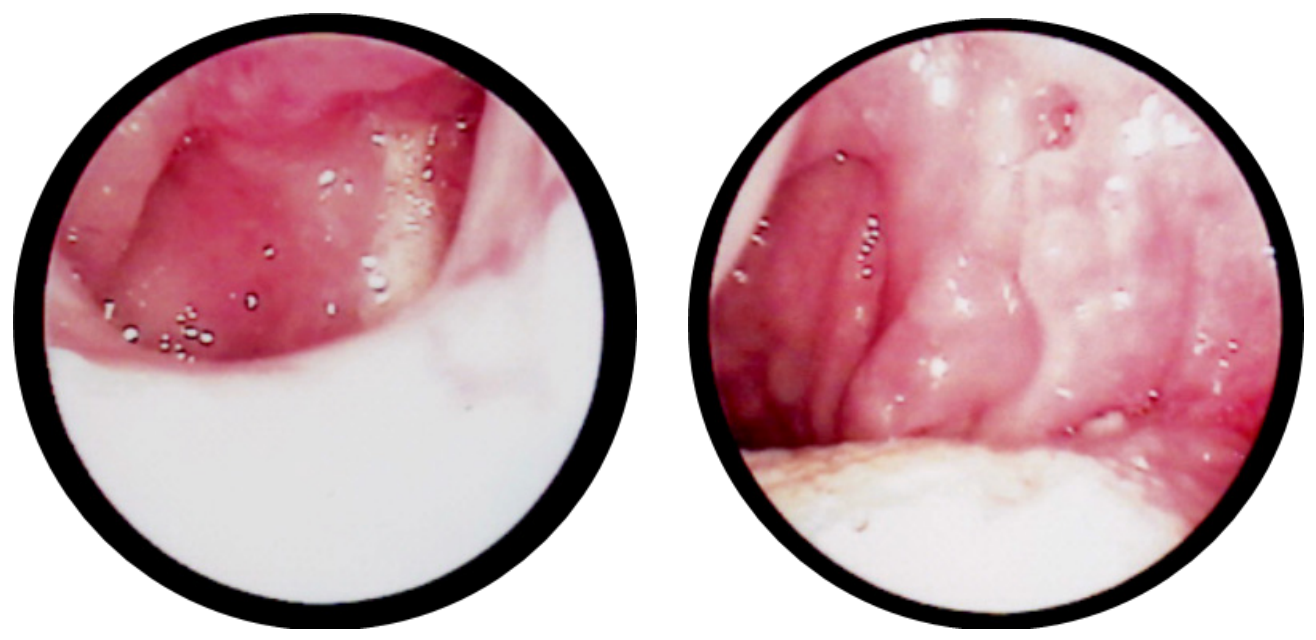

Gambar 3. Pembesaran pada tonsil

Pada pemeriksaan endoskopi (nasofaringoskopi) tampak dinding nasofaring sebelah kanan permukaannya tidak rata, kesan seperti massa nasofaring (gambar 2). Dari temuan tersebut dicurigai adanya suatu keganasan. Kemudian kami lakukan biopsi pada tonsil dan nasofaring dan didapatkan hasil histopatologi jaringan dengan kesimpulan adanya inflamasi kronik proses radang spesifik TBC pada tonsil dan nasofaring. Dari data hematologi didapat kesan adanya peradangan ringan (C-reaktif protein 12 mg/L, Leukosit 18.000/lap). Tes Mantoux didapat dengan hasil positif, seperti halnya pemeriksaan sputum (BTA tahan asam) sewaktu-pagisewaktu yang juga menunjukan hasil positif 2 . 


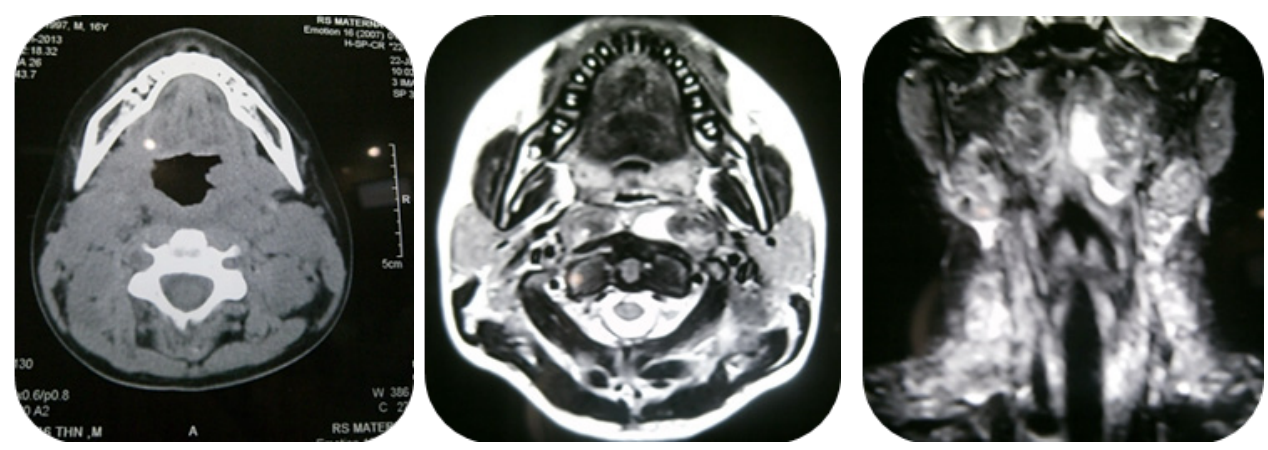

Gambar 4. Gambaran nasofaring dan leher
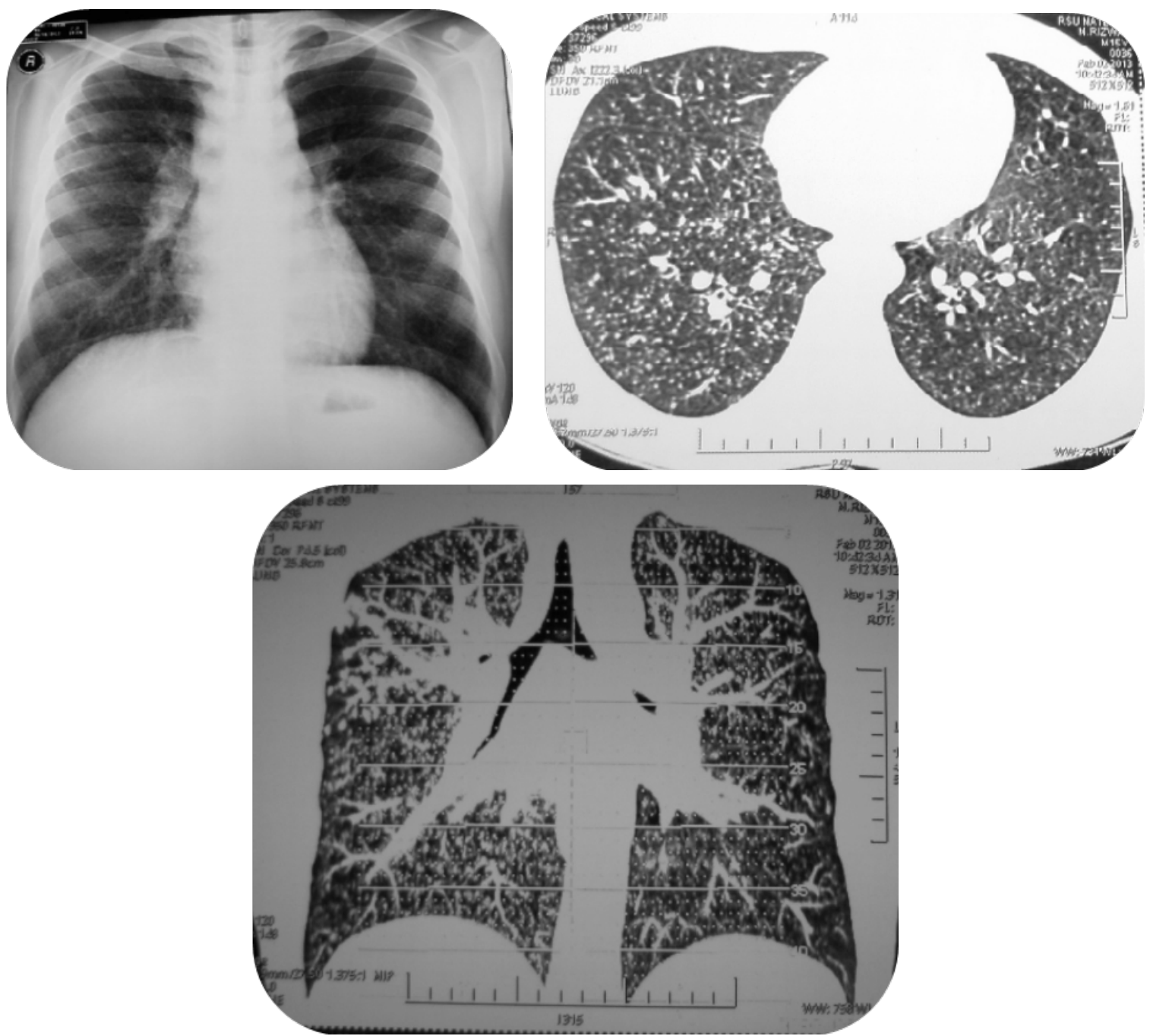

Gambar 5. Rontgen dan CT-Scan torax menunjukan adanya TB milier

Computed Tomography (CT) scan leher menunjukan penebalan jaringan lunak di daerah nasofaring bilateral. CT-Scan nasofaring dijumpai adanya limfadenopati servikal bilateral tanpa massa di nasofaring dan sinus (gambar 4). Rontgen toraks dan CT-Scan toraks menunjukkan lesi bronkogenik yang menyebar pada lobus paru, dengan penyebaran TB milier (gambar 5).

Pada pasien kami tegakan diagnosis TB 
tonsil dan nasofaring sertaTB milier disertai limfadenopati servikal. Pasien kami terapi dengan obat anti tuberkulosis yang terdiri dari isoniazid $300 \mathrm{mg} /$ hari $(5 \mathrm{mg} / \mathrm{Kg} \mathrm{BB})$, rifampisin $400 \mathrm{mg} / \mathrm{hari}(10 \mathrm{mg} / \mathrm{Kg} \quad \mathrm{BB})$, dan pirazinamid $1000 \mathrm{mg} /$ hari $(25 \mathrm{mg} / \mathrm{Kg}$ $\mathrm{BB})$ selama 2 bulan dilanjutkan dengan pemberian isoaniazid dan rifampisin selama 4 bulan. Setelah pemberian terapi anti tuberkulosis selama 1 bulan, pasien sudah tidak mengeluh nyeri dan sulit menelan, pembengkakan pada kelenjar limfe leher mengecil. Kontrol selanjutnya dijumpai temuan pada nasofaring dan tonsil yang normal dengan gambaran rontgen toraks tampak bersih.

\section{DISKUSI}

Diperkirakan sekitar 1,3 juta kasus TB dengan 450.000 kematian pada anak terjadi setiap tahun. TB lebih sering dijumpai pada lakilaki, meskipun demikian beberapa penelitian juga melaporkan insiden yang tinggi dijumpai pada wanita. ${ }^{1,2}$ TB ekstra-paru didefinisikan sebagai identifikasi Mycobacterium tuberculosis melalui pemeriksaan Ziehl-Nelsen dan biakan pada media Loewenstein-Jensen atau BACTEC dalam jaringan atau spesimen dari tempat selain parenkim paru, disertai dengan gejala klinis dan atau histopatologi adanya infeksi mikobakteri di tempat selain kelenjar getah bening hilus atau parenkim paru, serta hasil reaksi kulit tuberkulin tes positif dan atau dengan riwayat paparan tuberkulosis dan mengesampingkan kemungkinan penyakit lain. TB ekstraparu merupakan sepertiga dari semua kasus tuberkulosis yang ada. ${ }^{1,3,4}$

Tuberkulosis relatif jarang terjadi di bagian kepala dan leher. Manifestasi yang paling sering dijumpai di daerah ini adalah adanya limfadenopati servikal, sering melibatkan segitiga posterior dan khususnya daerah supraklavikula. Tuberkulosis juga dapat melibatkan kelenjar ludah, tonsil, rongga hidung dan telinga. Dijumpai tuberkulosis kepala dan leher sekitar 10-15\% kasus tuberkulosis paru, mayoritas dengan kelainan pada kelenjar getah bening kepala leher. ${ }^{4-6}$

Sekitar dua persen pasien dengan bukti TB paru aktif, menunjukkan adanya keterlibatan saluran pernafasan atas. Meskipun lokasi yang paling umum dijumpai adalah laring, struktur lain seperti lidah, palatum, tonsil, faring dan mukosa bukal juga mungkin terkena. ${ }^{7,8}$

Dengan kemajuan pengobatan tuberkulosis belakangan ini, infeksi mikobakteri tuberkulosis pada nasofaring dan tonsil sudah jarang dijumpai. Gejala yang paling umum dijumpai adalah limfadenopati servikal, diagnosis dapat dibuat melalui pemeriksaan histopatologi spesimen jaringan. ${ }^{3,9}$ Diagnosis harus didasarkan pada penemuan biakan mikobakteri tuberkulosis menggunakan media khusus (Lowenstein-Jensen, Middlebrook). Kehadiran basil tahan asam dengan pewarnaan Ziehl-auramine atau Neelsen dapat dipastikan adanya tuberkulosis, tetapi tidak pathogonomik. Meskipun demikian sangat penting untuk mengevaluasi penyakit secara keseluruhan, tanpa mengindahkan daerah anatomis yang berbeda yang mungkin dipengaruhi oleh kondisi patologis ini. ${ }^{4,9}$

Tuberkulosis tonsil primer sangat jarang sekali terjadi tanpa disertai adanya TB paru aktif. Pasien dengan limfadenopati servikal sering disertai tuberkulosis tonsil. Pada tuberkulosis tonsil biasanya disertai dengan keluhan sakit tenggorok disertai adanya limfadenopati servikal. Dengan temuan tersebut dan juga dijumpai keadaan tonsil yang abnormal, membuat sulit untuk membedakan TB tonsil dengan keganasan. Diagnosis tuberkulosis tonsil dibuat berdasarkan pada temuan histopatologi dan identifikasi basil tuberkulum. ${ }^{7,8}$

Tuberkulosis nasofaring merupakan jenis yang langka, dijumpai hanya kurang dari 1\% dari tuberkulosis yang ditemukan 
pada saluran pernapasan bagian atas, dan hanya ditemukan $0,12 \%$ dari semua jenis tuberkulosis. TB pada nasofaring adalah kondisi yang langka, bahkan kejadiannya di daerah endemik TB pun sangat jarang dijumpai. Hal ini disebabkan oleh efek inhibitor saliva dan saprophytes pada basil tuberkulosa. ${ }^{8}$

Melalui pemeriksaan secara endoskopi TB nasofaring dapat dijumpai dengan kondisi nasofaring yang normal atau mukosa nasofaring yang tidak rata disertai dengan adanya ulserasi, penonjolan dari dinding faring atau sebagai massa polypoid. Tanda yang paling umum dari keterlibatan nasofaring adalah limfadenopati servikal, terjadi pada sekitar $70 \%$ kasus. Gejala lain yang sering dijumpai meliputi batuk kronis, epistaksis, sumbatan hidung, tinitus, gangguan pendengaran, otitis media dan bahkan keterlibatan saraf kranial seperti diplopia. Presentasi klinis yang bervariasi ini membuat sulit mendiagnosis. ${ }^{9}$ Selain itu terdapat juga tuberkulosis nasofaring yang dijumpai tanpa keterlibatan kelenjar getah bening atau TB paru bahkan mungkin benar-benar asimptomatik, dengan demikian diagnosis hanya dapat ditegakan melalui pemeriksaan secara histopatologi. ${ }^{8,9}$

TB harus dipertimbangkan dalam diagnosis banding massa jaringan lunak kepala dan leher, terutama ketika dijumpai adanya pencitraan dan temuan klinis yang atipikal. Adanya nekrosis, peninggian batas jaringan sekitar, kalsifikasi, kelainan pada kelenjar limfe, dan temuan paru yang abnormal dapat mengarahkan kemungkinan diagnosis yang tepat, dengan tidak melupakan pemeriksaan biopsi dan mikrobiologi yang tepat. ${ }^{5}$ Pencitraan dengan $C T$ scan dan MRI sangat berharga pada kasus tuberkulosis di kepala dan leher untuk menunjukkan lokasi, pola, dan perluas penyakit. ${ }^{10}$ Pada kasus ini kami jumpai juga TB milier yang dibuktikan dari pemeriksaan Rontgen toraks dan CT Scan toraks.
Pengobatan untuk tuberkulosis paru dan extra-paru memiliki kesamaan, kecuali jika diketahui dan diduga kuat adanya resistensi kuman terhadap obat tuberkulosis lini pertama. Pengobatan pada TB tonsil dan nasofaring juga tetap menggunakan terapi dengan obat anti tuberkulosis. ${ }^{7,9}$

Pada kasus ini kami menemukan adanya keterlibatan tuberkulosis pada tonsil dan nasofaring sekaligus disertai adanya limfadenopati servikal bilateral yang awalnya diduga suatu keganasan di tonsil dan nasofaring. Pemeriksaan yang mendukung pun dilakukan. Pasien diberikan terapi dengan anti tuberkulosis berupa isoniazid, rifampisin dan pirazinamid. Setelah pemberian terapi anti tuberkulosis selama 2 bulan dijumpai perbaikan klinis dan radiologis yang signifikan pada pasien tersebut.

Sebagai kesimpulan dan saran, pada semua kasus yang mencurigakan, tes diagnostik TB perlu dipertimbangkan, khususnya ketika pemeriksaan patologi primer yang dilakukan tidak menghasilkan diagnosis yang pasti. TB harus dipertimbangkan dalam mendiagnosis banding massa jaringan lunak di kepala dan leher, terutama jika dijumpai temuan klinis maupun pencitraan yang atipikal. Adanya temuan paru yang abnormal dapat mengarahkan kemungkinan diagnosis yang tepat, dengan tidak melupakan pemeriksaan biopsi dan mikrobiologi yang tepat. Pada pasien yang kami laporkan dengan TB milier disertai TB tonsil dan nasofaring dengan limfadenopati servikal, yang awalnya dicurigai suatu keganasan setelah dilakukan pemeriksaan yang cermat dan diberikan terapi dengan obat anti tuberkulosis menunjukan perbaikan klinis dan radiologis yang signifikan.

\section{DAFTAR PUSTAKA}

1. Nalini MS, Vinayak S. Tuberculosis in ear, nose, and throat practice: its presentation and diagnosis. Am J Otolaryngol 2005; 07:005. 
2. Ainhoa GL, Armengot M, Calabuig C. Tuberculous pseudotumor of the rhinopharynx. Arch Bronconeumol 2011; 47:537-8.

3. Haghi, Rajati, Kaboli. A case of primary nasopharyngeal and tonsillar tuberculosis. Iran J Otorhinolaryngol 2009; 217-20.

4. Maltezou HC, Spyridis P, Kafetzis DA. Extra-pulmonary tuberculosis in children. Arch Dis Child. 2000; 83:342-6

5. Bharatha, Aditya, Bartlett, Eric S, Yu E. Pharyngeal and retropharyngeal tuberculosis with nodal disease. RSNA 2010; 254:629-32.

6. Callister M, Gregor MC. Diagnosis of tuberculosis in the head and neck. J Laryngol Otol 2011; 125:603-7.

7. Kant, Surya, Sanjay KV, Sanjay. Isolated tonsil tuberculosis. Lung India 2008; 25:163-4.

8. Aktan B, Selimoglu E, Ucuncu H, Sutbeyaz Y. Primary nasopharyngeal tuberculosis in a patient with the complaint of snoring. $\mathrm{J}$ Laryngol Otol 2002; 116:301-3.

9. Nieves, Cristina S, Onofre, Rubiliza, Corazon AAR, Fortuna, et al. Nasopharyngeal tuberculosis in a patient presenting with upper airway obstruction. Philipp J Otolaryngol Head Neck Surg 2010; 25:20-2.

10. Ito K, Morooka, Miyako, Kubota, Kazuo. 18F-FDG PET/CT finding of pharyngeal tuberculosis. Ann Nucl Med 2010; 24:493-6. 